\title{
Ta'dlb Dalam Kacamata Undang-Undang Nomor 23 Tahun 2004 Tentang Penghapusan Kekerasan Dalam Rumah Tangga (PKDRT) *
}

\section{(TA'DIB PERSPECTIVE OF LAW NUMBER 23 YEAR 2004 CONCERNING THE ELIMINATION OF DOMESTIC VIOLENCE (PKDRT))}

\author{
Muhammad Ishar Helmi \\ Magister Ilmu Hukum UPN Veteran Jakarta \\ Jl. RS. Fatmawati Pondok Labu Jakarta Selatan \\ Email: isharhelmi90@gmail.com
}

\begin{abstract}
Islamic Sharia gives guidance which is very straightforward in doing $t a^{\prime} d i b$. Generally many texts that ordered the husbands and parents apply gentle in doing $t a^{\prime} d i b$. However, Islam also gave guidance in the form of skill to beat if necessary. Included in this case when a wife do nushuz, then the husband can beat up in the realm of $t a^{\prime} d i b$ commanded by Allah and the Prophet PBUH. But this beating, although intended to include the category $t a^{\prime} d i b$ but makruh deed, and is expected to be avoided.
\end{abstract}

Keywords: Ta'dib, Domestic Violence, Nushuz

\begin{abstract}
Abstrak: Syariah Islam memberikan tuntunan yang sangat gamblang dalam melakukan $t a^{\prime} d i b$. Secara umum banyak nash yang memerintahkan para suami dan orangtua berlaku lemah lembut dalam melakukan $t a^{\prime} d i b$. Namun, Islam juga memberi tuntunan berupa kebolehan untuk memukul jika memang diperlukan. Termasuk dalam hal ini ketika seorang Istri melakukan nusyuz, maka sang suami dapat melakukan pemukulan dalam ranah $t a^{\prime} d i b$ yang diperintahkan oleh Allah Swt dan Rasul Saw. Akan tetapi pemukulan ini, walaupun diniatkan untuk ta' dib tetapi termasuk katagori perbuatan yang makruh, dan diharapkan untuk dihindari.
\end{abstract}

Kata Kunci: Ta'dib, KDRT, Nusyuz

* Diterima tanggal naskah diterima: 15 Juli 2014, direvisi: 27 Juli 2014, disetujui untuk terbit: 16 September 2014. 


\section{Pendahuluan}

Kata $t a^{\prime} d i b$ sering digunakan dalam istilah pendidikan yakni persamaan dari kata tarbiyah dan kata ta'lim. Ta'dib berasal dari kata addaba, yuaddibu, ta'diban yang artinya pendidikan (education) disiplin, patuh dan tunduk pada aturan (discipline) peringatan atau hukum (punishment) hukuman-penyucian (chastisement). ${ }^{1}$ Ta'dib diterjemahkan dengan perjamuan makan atau pendidikan sopan santun. ${ }^{2}$ Sedangkan kata $t a^{\prime} d i b$ dalam pembahasan ini yakni pemberian pembelajaran atau pendidikan terhadap seorang isteri yang nusyuz terhadap suaminya.

Syariah Islam telah menetapkan kewajiban bagi suami untuk mendidik (men-ta'dib) istri dan anak-anaknya agar taat kepada Allah SWT. Hal ini sesuai dengan firman Allah SWT:

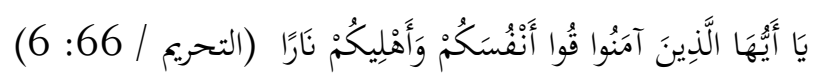

"Wahai orang yang beriman, jagalah diri kalian dan keluarga kalian dari api neraka".

Syeikh Nawawi, Muhammad bin Umar an-Nawawi al-Bantani menuturkan beberapa alasan yang memperbolehkan suami untuk memukul isterinya, yakni jika si isteri tidak mau menghiasi dirinya pada si suami menghendaki, tidak memenuhi ajakan suami untuk berhubungan intim, keluar rumah tanpa seizin suami, memegang janggut suami, memperlihatkan muka kepada orang lain, berbicara dengan orang lain yang bukan mahram atau berbicara kepada suami dengan suara lantang agar terdengar orang lain, mengatakan ucapan "keledai atau bodoh" kehadapan suami sekalipun karena dihardik oleh suami, merobek baju suami, memukul anak kecil yang sedang menangis, jika isteri memberikan kepada orang lain dari rumah suami sesuatu yang semestinya harus disimpan dan dirawat. ${ }^{3}$

$T a^{\prime}$ dib kepada istri dan anak suami harus dilakukan secara bersungguh-sungguh, karena suamilah yang bertanggung jawab dalam mengarahkan dan mengatur bahtera rumah tangga. Jika suami berhasil

1 Tahzib, wa'dz, mau'idzah, riyadhah, tazkiyah, talqil, tadris, tafaqquh, tabyin, tazkirah dan irsyad. Lihat, Abuddin Nata, Ilmu Pendidikan Islam (Jakarta: Kencana Prenada Media Group, 2010), h. 47.

2 Mahmud Yunus, Kamus Arab-Indonesia, (Jakarta: YP3A, 1987), h.149.

3 Faqihuddin Abdul Kodir dkk, Referensi Bagi Hakim Peradilan Agama Tentang Kekerasan Dalam Rumah Tangga, h, 48. 
mengarahkan istri dan anak, sehingga mereka menjadi individu yang berkepribadian Islam dan siap mengarungi kehidupan sebagai Hamba Allah, maka suami akan sukses mengemban amanahnya sebagai qawwam (pemimpin) dalam sebauah bahtera rumah tangga.

Syariah Islam memberikan tuntunan yang sangat gamblang dalam melakukan $t a^{\prime} d i b$. Secara umum banyak nash yang memerintahkan para suami dan orangtua berlaku lemah lembut dalam melakukan $t a^{\prime} d i b$. Namun, Islam juga memberi tuntunan berupa kebolehan untuk memukul "jika memang diperlukan." Salah satu dalil tentang tuntunan bagi para suami ketika menta'dib istrinya adalah ayat berikut:

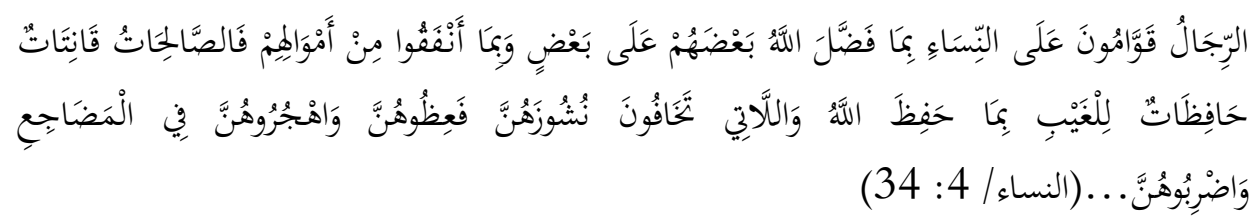

"Laki-laki adalah pemimpin kaum perempuan karena Allah telah melebihkan sebagian mereka (laki-laki) atas sebagian yang lain (perempuan), karena mereka telah menafkahkan sebagian dari harta mereka. Karena itu, wanita shalihah adalah yang taat kepada Allah dan memelihara diri ketika suaminya tidak ada karena Allah telah memelihara mereka. Istri-istri yang kalian khawatirkan nusyuz mereka maka nasihatilah mereka, pisahkanlah mereka di tempat tidur mereka dan pukullah mereka...".

Ayat ini menggambarkan tentang konsep kepemimpinan suami dalam rumah tangga serta ketaatan istri kepada suami. Dikatakan bahwa laki-laki adalah pemimpin rumah tangga karena keutamaannya dan laki-laki bertanggung jawab dalam memenuhi nafkah istri dan keluarganya. Istri yang baik (shalihah) adalah yang taat kepada Allah dan memelihara diri (tidak curang, memelihara rahasia dan harta suaminya ketika suaminya tidak ada di rumah). Saat istri membangkang (nusyûz) dengan tidak menjaga dirinya dari curang, menolak diajak jimak, atau keluar rumah tanpa izin dari suaminya, maka suami boleh menempuh langkah-langkah, seperti; menasehati, pisah ranjang, dan bila perlu memukul untuk men-ta'dib istrinya. Dalam Islam diperbolehkan untuk melakukan pukulan sebagai $t a^{\prime} d \hat{\imath} b$, syeikh Nawawi banten menuturkan bahwa yang diizinkan adalah pukulan yang terukur dan terbatas. ${ }^{4}$

${ }^{4}$ Ibid. 
Memukul istri atau anak dalam rangka ta'dib tidak boleh diterjemahkan sebagai "kekerasan dalam rumah tangga", karena kekerasan adalah bentuk kriminalitas (jarimah). Pengertian jarimah sendiri dalam Islam adalah tindakan melanggar hukum syariah Islam dan termasuk kategori kejahatan. Kejahatan dalam Islam adalah perbuatan tercela (al-qabih) yang juga ditetapkan oleh hukum syariah, bukan oleh yang lain. Apa yang dianggap sebagai tindakan kejahatan harus distandarkan pada hukum $t$ terhadap ancaman Allah atau terhadap kemadaratan akibat ancaman terputusnya nafkah. Bahkan jika hajr (pemisahan tempat tidur) dengan maksud suami "tidak menyentuhnya" agar istri jera juga tidak membawa perubahan pada dirinya, saat seperti inilah dibutuhkan cara lain untuk memperbaikinya, yaitu dengan pukulan. Demikian juga pada anak, bila pendidikan tidak bisa lagi diberikan dengan cara memberikan nasihat, arahan, petunjuk, kelembutan ataupun suri teladan, maka dalam kondisi seperti ini kadang dibutuhkan pukulan.

Hanya saja, harus diperhatikan, $t a^{\prime} d i b$ kepada istri dan anak dengan pukulan ini bukanlah sebagai penghinaan atasnya, bukan pula balas dendam atau penyiksaan; tetapi dalam rangka mendidik, memperbaiki dan meluruskan. Pukulan ini disertai rasa kasih sayang suami kepada istri atau orangtua kepada anaknya, bukan pukulan yang keras, sehingga membuat istri lari dari suaminya, anak menjauh dari orang tuanya, karena menumbuhkan kebencian dan memupus rasa cinta. Di dalam fiqih, pukulan ada yang diistilahkan dharb mubarrih dan ada dharb ghairu mubarrih.

1. Dharb mubarrih ialah pukulan yang keras hingga dikhawatirkan akan mematahkan tulang, menghilangkan nyawa, atau membuat cacat anggota tubuh. Pukulan seperti ini dilarang oleh syariah dan termasuk perkara yang diharamkan.

2. Dharb ghairu mubarrih ialah pukulan ringan yang tidak mengucurkan darah serta tidak dikhawatirkan menimbulkan kebinasaan jiwa atau cacat pada tubuh, patah tulang, dan sebagainya.

Pukulan jenis kedua ini menurut syariah boleh diberikan kepada istri yang berbuat nusyuz, bermaksiat dan melakukan pelanggaran syariah, setelah dilakukan maw'izhah dan hajr. ${ }^{5}$ Para fuqaha mengatakan, dharb ghairu mubarrih

${ }^{5}$ Shalih bin Ghanim as-Sadlan, an-Nusyuz "Dhowabituhu, haalatuhu, asbabuhu, turqul wiqoyah minhu wasaili ilajihi fii du'i al-Qur'an wa Sunnah, (Riyadh: al-Mamlakah al-Arabiyah asSu'udiyah, 1415 H/1996 M), Cet. 2, h. 44-45. 
adalah pukulan yang tidak melukai si istri, tidak mematahkan tulangnya, tidak membuat bekas yang jelek pada tubuhnya dan tidak boleh diarahkan pada wajah karena wajah tempat terkumpulnya kecantikan. Pukulan tersebut juga harus berpencar pada tubuhnya (tidak diarahkan hanya pada satu tempat). Tidak boleh satu tempat dipukul terus-menerus, agar tidak menimbulkan bahaya yang besar pada bagian tubuh tersebut. Di antara fuqaha ada yang menyatakan, "Sepantasnya pukulan dilakukan dengan menggunakan sapu tangan yang dililit atau dengan tangan si suami, tidak boleh dengan cambuk dan tongkat."

Banyak ulama yang mendeskripsikan pukulan yang terukur, yaitu pukulan dengan siwak atau kayu pembersih gigi. Atha' rahimahullahu berkata:

Aku pernah bertanya kepada Ibnu Abbas radhiyallahu 'anhuma, "Apa yang dimaksud pukulan ghairu al-mubarrih?" Ibnu Abbas ra menjawab, "Memukul dengan siwak dan semisalnya." 6

Beberapa ulama memperkenankan pemukulan yang berlebihan, bahkan yang menistakan sekalipun. ${ }^{7}$ Misalnya, dalam sebuah tafsir yang ditulis Abu Hayyan al-Andalusi al-Bahr al-Muhith, dinyatakan bahwa:

Dalam menghadapi isteri yang nusyuz, seorang suami mengawali dengan nasehat yang lembut, jika tidak bermanfaat, maka bisa dengan kata-kata kasar, kemudian meninggalkan ranjang dan tidak menggaulinya, kemudian dengan berpaling dari isteri sepenuhnya, kemudian bisa memukul dengan cambuk atau galah lebu atau sejenisnya yang membuatnya sakit dan jera, tetapi tidak boleh mematahkan tulang atau mengucurkan darah. Jika semua itu tidak membuahkan hasil, suami bisa mengikat sang isteri ke sudut tempat dengan tali, lalu dipaksa melayani hubungan intim. Karena semua itu adalah hak suami. ${ }^{8}$

Dalam sebuah perkawinan yang dibangun dalam bentuk sebuah bahtera rumah tangga, suami dan isteri memiliki hak-haknya dalam sebuah perkawinan, antara lain:

${ }^{6}$ Muhammad Ibnu Jarrir Ibnu Yazid Ibnu Katsir Ibnu Gholib al-Amali (Abu Ja'far atThabari), Tahqiq Ahmad Muhammad Syakir, Tafsir Jaami' al-Bayan Fii Ta'wil al-Qur'an, (Mesir: Mu'asasah ar-Risalah, 2000) cet. 1, Juz 8, Bab 34, h. 315.

7 Ibid.

${ }^{8}$ Muhammad Ibnu Yusuf as-Syahir bi Abi hayyan al-Andalusi, Tahqiq as-Syeikh 'adil Ahmad Abdul Maujud dan Syeikh Ali Muhammad Mu'awid, Tafsir al-Bahr al-Muhit, (Beirut: Daar al-Kutub al-Alamiyah, 2001) Cet. 1, Juz 3, h. 252. 
- Hak Suami; ${ }^{9}$ Penjagaan ketika suami tidak berada di rumah, hak suami atas isterinya ialah bahwa isteri harus benar-benar menjaga segala sesuatu yang menjadi milik suaminya, ketika suami di luar rumah. Firman Allah:

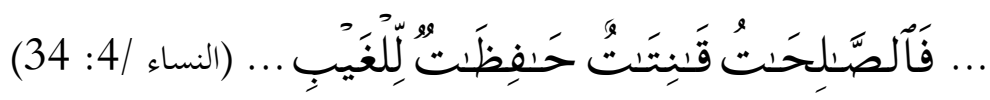

“...Karena itu, perempuan-perempuan yang shalihat adalah yang taat beribadat, menjaga amanat serta kehormatannya ketika kepergian suaminya.".

- Kepatuhan, seorang isteri harus patuh terhadap suaminya. Bila seorang isteri tidak mematuhi suaminya, atau tidak menghiraukan sesuatu yang menjadi hak suami, maka mula-mula suami harus menasehatinya, jika hal tersebut tidak ada pengaruhnya, suami berhak untuk secara wajar, bersikap tegas dalam menghadapinya, dan jika hal ini juga tidak dapat mengatasi hal tersebut, suami boleh memberikan pukulan yang tidak terlalu keras kapada isterinya agar ia sadar dan jera dan segera mematuhinya. Sebagaimana telah disebutkan dalam firman Allah QS. an-Nisa: $34 .^{10}$

- Perceraian, jika suami sudah tidak sanggup lagi untuk hidup bersama dengan catatan suami sudah berusaha untuk menasehati, melakukan perdamaian, membimbing isteri maka suami boleh menceraikan isterinya.

Menurut Muhammad Khair ash Shalih (2006:269), hak-hak suami yang terpenting atas isterinya ialah: ${ }^{11}$

a. Menghormati, mendengar, mematuhi hal-hal yang disukai atas dibenci dalam segala aktivitas dan hal-hal yang tidak berguna, kecuali mengajak maksiat.

b. Isteri menerima ajakan suami untuk bersenggama, kecuali jika ia mengalami hal-hal yang tidak memungkinkan.

${ }^{9}$ Abul a'la al-maududi dan Fazl Ahmed, The Laws of Marriage and Divorce In Islam, (Kuwait: Islamic Book Publisher, 1983) Cet. 9, h. 23-24.

${ }^{10}$ Ibid. h. 30-32.

${ }^{11}$ Mustofa Hasan, Mustofa Hasan, Pengantar Hukum Keluarga, (Bandung: CV Pustaka Setia, 2011), h. 178. 
c. Isteri tidak boleh memasukan orang ke dalam rumah, sedangkan orang tersebut adalah orang yang dibenci oleh suaminya.

d. Isteri selalu meminta izin kepada suami jika hendak keluar rumah.

e. Isteri tidak berpuasa sunnah, kecuali suaminya mengizinkan.

f. Semua harta yang akan diambil manfaat harus atas izin suami.

g. Isteri menjaga rumah dan mendidik anak-anak dengan pendidikan islami.

h. Isteri tidak meminta cerai, kecuali alasan yang sangat kronis.

i. Isteri tidak menyebarluaskan kelemahan suami dalam segala hal.

2. Hak Isteri

Hak-hak yang pada hakikatnya harus diterima oleh isteri merupakan upaya Islam untuk mengangkat harkat dan martabat kaum perempuan pada umumnya. Pada masa jahiliyah di jazirah Arab hak-hak perempuan hampir tidak ada dan yang terlihat hanyalah kewajiban semata. Hal ini disebabkan karena status perempuan pada saat itu dianggap sangat rendah dan hampir dianggap sesuatu yang tidak berguna. Hal itu terjadi karena situasi dan kondisi pada saat itu memerlukan kekuatan fisik untuk mempertahankan hidup. $^{12}$

Hak isteri antara lain, yaitu: Pertama, hak menerima mahar yang mana kewajiban suami untuk memberikan mahar. Kedua, Hak digauli dengan baik, hal ini merupakan kewajiban seorang suami menggaulinya dengan baik. Namun suami pun berhak digauli dengan baik oleh isterinya, akan tetapi penekanan hukum Islam lebih dominan kepada isteri. Ketiga, hak isteri sebagai ibu rumah tangga, firman Allah QS. Luqman : 14 yaitu:

"Dan kami perintahkan kepada manusia (agar berbuat baik) kepada kedua orang tuanya. Ibunya telah mengandungnya dalam keadaan lemah yang bertambah-tambah, dan menyapihnya dalam usia dua tahun. Bersyukurlah kepada-Ku dan kepada kedua orang tuamu. Hanya kepada-Kulah kamu kembali."

12 Ibid. 153. 
Syeikh Nawawi, Muhammad bin Umar an-Nawawi al-Bantani dalam kitab Uqudu Lujain Fii Bayaani Huquuzzaujaini menuturkan tentang hak-hak isteri atas suami dalam sabda Rasulullah SAW yaitu: ${ }^{13}$

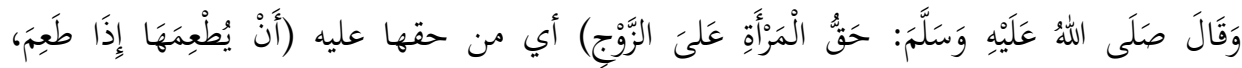

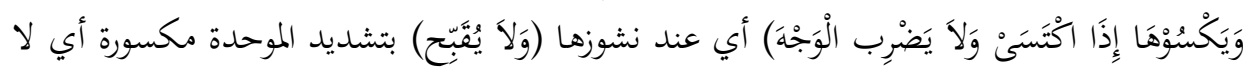

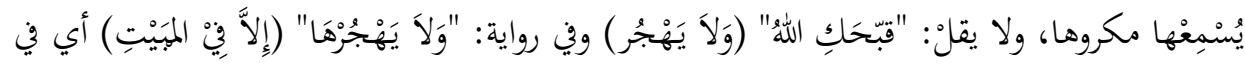

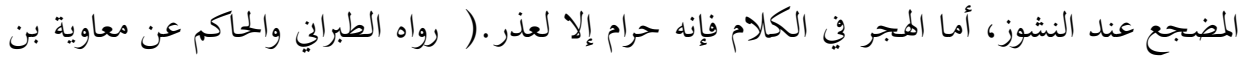

$$
\begin{aligned}
& \text { حيدة بنتح المهملة). }
\end{aligned}
$$

"Hak Isteri atas Suami ialah memberi makan kepadanya jika ia makan, memberi pakaian kepadanya apabila ia berpakaian, dan jangan menampar wajah, jangan menjelek-jelekan dan jangan membiarkan (memisahkannya) kecuali dalam tempat tidur." (HR. Thabrani dari Muawiyah bin Hadyah).

\section{Batasan-batasan Kekerasan Dalam Rumah Tangga Perspektif Undang- Undang nomor 23 Tahun 2004 Tentang Penghapusan Kekerasan Dalam Rumah Tangga}

Mayoritas Kekerasan Dalam Rumah Tangga (KDRT) dialami oleh isteri yang dilakukan oleh suaminya, karena isteri merupakan objek yang lemah dan tidak berdaya, meskipun memang ada pula kekerasan yang dilakukan oleh isteri kepada suaminya, seperti isteri yang membunuh dan memutilasi suaminya sendiri. Kekerasan Dalam Rumah Tangga (KDRT) terhadap isteri ialah bentuk kriminaltas (jarimah). Dalam Islam kriminalitas merupakan tindakan melanggar peraturan yang telah ditetapkan oleh syariat Islam dan dikategorikan kejahatan. Adapun kejahatan dalam Islam merupakan perbuatan tercela (al-qabih) yang ditetapkan oleh hukum syara' bukan yang lain dan perbuatan yag dianggap sebagai tindakan kejahatan terhadap perempuan harus distandarkan pada hukum syara' ${ }^{14}$

Terdapat banyak bentuk pelanggaran kekerasan dalam rumah tangga, seperti yang marak dan realitanya dirasakan oleh kaum perempuan atau lakilaki yang menerima perlakuan kekerasan dalam rumah tangga. Di dalam

13 Syeikh Muhammad bin Umar an-Nawawi, Uqudu Lujain Fii Bayaani Huquuzzaini, (Surabaya: Daar Ulum, TT), h. 4.

${ }^{14}$ Mustofa Hasan, Pengantar Hukum Keluarrga, h. 363. 
pasal 5 Undang-Undang nomor 23 tahun 2004 tentang Penghapusan Kekerasan Dalam Rumah Tangga yaitu larangan melakukan kekerasan dalam rumah tangganya yaitu dengan cara; 1). Kekerasan Fisik, 2). Kekerasan Psikis, 3). Kekerasan Seksual, atau 4). Penelantaran Rumah Tangga.

Dalam Undang-Undang PKDRT kekerasan fisik adalah perbuatan yang mengakibatkan rasa sakit, jatuh sakit, atau luka berat. ${ }^{15}$ Kekerasan fisik merupakan bentuk kekerasan yang secara langsung dirasakan oleh fisik, misalnya memukul dan membunuh. ${ }^{16}$ Korban kekerasan fisik, biasanya ia telah mengalami kekerasan psikis sebelum dan sesudahnya. Kekerasan fisik bisa muncul dalam berbagai bentuk dan rupa, mulai dari menampar, menempeleng, memukul, membanting, menendang, membenturkan ke benda lain sampai bisa menusuk dengan pisau bahkan membakar. ${ }^{17}$

Kekerasan psikis yang mengarah pada serangan terhadap mental/psikolog seseorang, kekerasan ini berupa kekerasan yang mengakibatkan perasaan tertekan, stres, dan munculnya penyakit didalam hati. ${ }^{18}$ Kekerasan terhadap psikis ini paling banyak kasus-kasus yang dilaporkan ke lembaga-lembaga pendamping. ${ }^{19}$ Bahkan, hal ini banyak dijadikan alasan sebagai salah satu unsur seorang isteri mengajukan cerai gugat. Kata-kata kotor, ucapan-ucapan menyakitkan, bentakan, penghinaan, dan juga ancaman yang merupakan bentuk-bentuk dari kekerasan psikis, banyak perempuan dalam hal ini dijadikan sasaran pelampiasan, bisa jadi karena faktor masalah yang terjad di luar rumah tangga. Namun, tidak sedikit juga hal tersebut diputarbalikan posisinya yakni memutarbalikan fakta, suami menempatkan isteri sebagai pelaku KDRT dan suami menjadi korbannya.

Sang suami mengungkapkan "isteri saya menyakiti saya karena berbicara dengan laki-laki lain; ia sengaja menghina saya dengan menyediakan makanan yang tidak saya sukai ia sama sekali tidak menghormati saya sebagai suami." 20

${ }^{15}$ Pasal 6 Undang-Undang Nomor 23 Tahun 2004 Tentang Penghapusan Kekerasan Dalam Rumah Tangga.

${ }^{16}$ Mustofa Hasan, Pengantar Hukum Keluarrga, h. 364.

17 Faqihuddin Abdul Kodir dkk, Referensi Bagi Hakim Peradilan Agama Tentang Kekerasan Dalam Rumah Tangga, h. 32.

${ }^{18}$ Mustofa Hasan, Pengantar Hukum Keluarrga, h. 364.

19 Faqihuddin Abdul Kodir dkk, Referensi Bagi Hakim Peradilan Agama Tentang Kekerasan Dalam Rumah Tangga, h.32.

${ }^{20}$ Ibid. 
Sebagaimana disebutkan dalam pasal 7 Undang-Undang Nomor 23 tahun 2004 tentang Penghapusan Kekerasan Dalam Rumah Tangga yaitu perbuatan yang mengakibatkan ketakutan, hilangnya rasa percaya diri, hilangnya kemampuan untuk bertindak, rasa tidak berdaya, dan/atau penderitaan psikis berat terhadap seseorang.

Pasal 8 UU PKDRT kekerasan seksual meliputi pemaksaan hubungan seksual yang dilakukan terhadap orang yang menetap dalam lingkup rumah tangga tersebut. Pemaksaan hubungan seksual terhadap salah seorang dalam lingkup rumah tangganya dengan orang lain untuk tujuan komersial dan atau tujuan tertentu. Kekerasan seksual yaitu kekerasan yang mengarah kepada seksualitas seseorang, yakni dapat berupa pemaksaan hubungan seksual atau perkosaan, pemukulan dan bentuk-bentuk kekerasan lain yang menyertai hubungan intim; bisa sebelum atau sesudah berhubungan suami istri, pemaksaan dalam berbagai posisi dan kondisi dalam berhubungan seksual, pemaksaaan aktivias tertentu, pornografi, penghinaan terhadap seksualitas perempuan melalui bahasa verbal ataupun juga pemaksaan terhadap istri untuk terus-menerus hamil ataupun menggugurkan kehamilan. Biasanya kekerasan seksual ini disertai dengan kekerasan lain, baik kekerasan terhadap fisik, mental, maupun ekonomi, yang pastinya tidak hanya berdapak pada organ seks/reproduksi secara fisik, tetapi juga berdampak pada kondisi psikis atau mental seseorang.

Penelantaran rumah tangga, suami sebagai kepala keluarga memiliki kewajiban untuk menafkahi juga mengurusi keluarganya. Kekerasan ini berdimensi ekonomi yang dialami perempuan, sekalipun pihak suami ditempatkan sebagai kepala rumah tangga, namun tidak sedikit dari pihak suami menelantarkan isteri dan anak-anak mereka, melarang istri untuk bekerja tetapi juga tidak memberikan uang atau pendapatan yang cukup untuk keluarga. ${ }^{21}$ Hal ini diatur juga dalam pasal 9 UU No. 23 tahun 2004 tantang PKDRT.

Kekerasan Dalam Rumah Tangga (KDRT) merupakan segala bentuk kekerasan yang terjadi dalam lingkup rumah tangga. Dalam Undang-Undang nomor 23 tahun 2004 tentang Penghapusan Kekerasan Dalam Rumah Tangga (PKDRT) menyebutkan bahwa lingkup rumah tangga dalam Undang-Undang meliputi suami, istri dan anak, orang-orang yang mempunyai hubungan keluarga dengan orang sebagaimana karena hubungan darah, perkawinan,

\footnotetext{
${ }^{21}$ Ibid.
} 
persusuan, pengasuhan, dan perwalian yang menetap dalam rumah tangga tersebut, orang yang bekerja membantu rumah tangga dan menetap dalam rumah tangga tersebut.

Pembantu rumah tangga atau orang yang bekerja sebagai pembantu rumah tangga juga termasuk dalam lingkup rumah tangga, karena selama dia berada dalam rumah tangga tempat dia bekerja dalam jangka waktu tersebut dia dianggap sebagai anggota keluarga.

Setiap orang dalam rumah tangga berpotensi menjadi korban kekerasan, siapapun yang merasa tersubordinasi dan menerima perlakuan kekerasan oleh pihak lain dalam rumah tangga tersebut. Sehingga korban Kekerasan Dalam Rumah Tangga (KDRT) bisa saja suami, istri, anak, anggota keluarga yang hidup dalam rumah tangga dan orang yang bekerja dalam rumah tangga tersebut misalnya pembantu rumah tangga .

\section{Kekerasan Dalam Rumah Tangga (KDRT) Menurut Tinjauan Hukum Islam}

Pernikahan merupakan persoalan pilihan pasangan hidup, yang tentu harus dukembalikan kepada kedua calon mempelai. Dalam fiqih sendiri sudah dinyatakan bahwa persoalan pilihan ini bertumpu pada kedewasaan dan kematangan seseorang (al-Bulugg wa ar-Ruhsd), bukan pada jenis kelamin. Terkadang sebuah pilihan tersebut menjadi tolak ukur langgengnya sebuah bahtera rumah tangga. maka ia berhak untuk menentukan pilihan menyangkut dirinya. ${ }^{22}$

Dalam Islam dikenal istilah nusyuz yang memiliki arti durhaka kepada suami yakni menentang kehendak suami tanpa alasan yang diterima menurut hukum syara' tindakan tersebut dipandang durhaka. Apabila istri durhaka, suami hendaknya tidak bersifat temperamental, ia harus menasehatinya dengan lemah lembut dan penuh dengan rasa kasih sayang. Apabila sudah dinasehati, tetapi masih terus durhaka, hendaklah suami berpisah tidur dengan isteri, dan jika masih juga belum sadar maka suami diperbolehkan untuk memukulnya, tetapi dengan pukulan yang terukur. ${ }^{23}$

${ }^{22}$ Faqihuddin Abdul Kodir dkk, Referensi Bagi Hakim Peradilan Agama Tentang Kekerasan Dalam Rumah Tangga, h. 53.

${ }^{23}$ Mustofa Hasan, Pengantar Hukum Keluarrga, h.367-368. 
Dalam prakteknya, sekalipun mayoritas ulama memberikan aturan pemukulan, tetapi banyak sekali kasus-kasus yang melampau batasan-batasan yang telah digariskan. Kasus-kasus tersebut tidak sedikit yang mengatasnamakan kebolehan dari Islam. Dalam hal ini terdapat pandangan yang lebih tegas, pandangan secara jelas menyatakan bahwa pemukulan terhadap isteri pada dasarnya adalah makruh. Pandangan ini dinyatakan Imam atha'24, Ibnu Arabi seoarang ulama besar dari mazhab maliki mengutip pandangan ini pada tafsirnya ahkam Alquran: ${ }^{25}$

"Ini pandangan fiqih Imam Atha, dengan pemahamannya yang dalam terhadap syari'ah dan ketekunannya menggeluti soal-soal ijtihad, dia meyakini bahwa redaksi "pukullah" pada ayat ini adalah hanya menunjukkan kebolehan saja. Tetapi dia sendiri memilih menyatakan (bahwa memukul itu hukumnya) makruh, dengan argumentasi lain. Yaitu hadis Nabi SAW. Yang diriwayatkan Abdullah bin Zam'ah, bahwa Nabi Saw. bersabda: "Sesungguhnya aku tidak senang (benci) terhadap lelaki yang memukul isterinya ketika dia marah, padahal bisa saja setelah itu menggaulinya pada hari yang sama". (Ibnu Arabi: Juz I, h. 420).

Kebolehan memukul dalam QS. an-Nisa:34 bukanlah bersifat mutlak, tetapi ia diikat dengan berbagai perintah pada ayat-ayat lain, dan teladan Nabi Saw. Menegaskan betapa konflik dalam keluarga Nabi Saw., tidak pernah dan tidak perlu diselesaikan dengan media pemukulan. Beberapa pernyataan Nabi Saw., juga dengan tegas menyatakan larangan pemukulan terhadap isteri. Pernyataan lain: "mereka suami suka memukul isteri bukanlah orang-orang yang terbaik. (HR. Abu Dawud).

Dalam riwayat Bahzt bin Hakim bin Muawiyah, bahwa kakekya bertanya kepada Nabi Saw., "wahai Rasulullah, apa hak isteri kita, dan apa yang boleh kita lakukan dengannya dan apa yang tidak boleh dilakukan? Nabi Saw., menjawab: "kamu berhak menggauli isterimu bagaimanapun kamu suka, kamu harus memberi makan dari yang kamu makan, memberinya pakaian seperti yang kamu pakai, jangan mencemooh didepan wajah dan jangan memukulnya." (HR. Abu Dawud) lihat Ibnu al-Atsir, VII/329, no. hadis: 4717. Dalam riwayat lain dari Abdullah bin Zam'ah Rasulullah Saw. bersabda: "Janganlah sekali-kali seseorang diantara kamu memukul isterinya, layaknya hamba saja, padahal dipenghujung hari ia

\footnotetext{
${ }^{24}$ Seorang tabi'in yang berguru langsung kepada sahabat Nabi SAW.

${ }^{25}$ Faqihuddin Abdul Kodir dkk, Referensi Bagi Hakim Peradilan Agama Tentang Kekerasan Dalam Rumah Tangga,h. 49.
} 
mungkin akan menggaulinya." (HR. Bukhari, Muslim, dan Turmudzi) lihat Ibnu al-Atsir, VII/329, no. hadis: 4718.

\section{Penutup}

Kekerasan sama sekali tidak sesuai dengan perilaku, nasihat dan peringatan Nabi Saw. Pemukulan atau segala bentuk perilaku kekerasan terhadap isteri bukan merupakan bentuk pergaulan yang baik (mu'asyarah biil $m a^{\prime}$ ruf) seperti diperintahkan Alquran, tidak sesuai dengan anjuran penghormatan terhadap perempuan (ma akramahunna ilaa karim) dan bentuk pelanggaran terhadap wasiat Nabi Saw., untuk berbuat baik terhadap perempuan (Ishtaushu bin Nisa Khairan). Lebih dahsyat lagi, mereka yang memukul isteri dicap Nabi Saw. sebagai orang-orang yang jahat dan busuk (laysa ulaika bikhiyarikum). Memukul isteri, apapun alasannya adalah bertentangan dengan anjuran, harapan dan perilaku sehari-hari Nabi Saw. terhadap para isteri.

Nabi Saw sendiri bersedia bersabar ketika menghadapi berbagai perbedaan dan perlakuan dari isteri beliau. Bahkan memberikan kesempatan kepada mereka untuk mengekpresikan keinginan mereka, memberikan masukan dan menentukan pilihan yang sesuai dengan harapan mereka. Nabi Saw. tidak pernah menggunakan media kekerasan, kata-kata penghinaan, ucapan kotor, apalagi pemukulan. Mungkin Nabi Saw. terkadang membiarkan mereka yang melakukan pemukulan, beberapa sahabat juga melakukan, atau para ulama sendiri memperkenankan dengan batasanbatasan tertentu. Ini semua harus dipahami sebagai proses pelarangan yang bertahap, yang tidak bisa serta merta karena kondisi sosial yang belum memungkinkan. Tetapi secara prinsip, kekerasan dan pelecehan tidak diperkenankan dalam Islam. Hal tersebut diperkenankan ketika nyata memberikan dampak positif pada proses pendidikan (lil islah bainahuma). Ketika hal tersebut memberikan dampak positif, maka ia akan kembali pada hukum semula haram. Nabi Saw. sendiri tidak menganjurkan dan tidak melakukannya sepanjang hidup beliau. ${ }^{26}$

${ }^{26}$ Ibid. h. 49-51. 


\section{Pustaka Acuan}

Al-Qur'an Al-Karim.

al-Amali, Muhammad Ibnu Jarrir Ibnu Yazid Ibnu Katsir Ibnu Gholib, (Abu Ja'far at-Thabari), Tahqiq Ahmad Muhammad Syakir, Tafsir Jaami' alBayan Fii Ta'wil al-Qur'an, Mesir: Mu'asasah ar-Risalah, 2000) cet. 1, Juz 8, Bab 34.

al-Andalusi, Muhammad Ibnu Yusuf as-Syahir bin Abi hayyan, Tahqiq asSyeikh 'adil Ahmad Abdul Maujud dan Syeikh Ali Muhammad Mu'awid, Tafsir al-Bahr al-Muhit, Beirut: Daar al-Kutub al-Alamiyah, 2001 Cet. 1, Juz 3.

al-maududi, Abul a'la, dan Prof. Fazl Ahmed, The Lasw Of Marrieage and Divorce In Islam, Kuwait: Islamic Book Publisher, 1983.

an-Nawawi, Syeikh Muhammad bin Umar, Uqudu Lujain Fii Bayaani Huquuzzaini, Surabaya: Daar Ulum, TT.

as-Sadlan, Shalih bin Ghanim, an-Nusyuz "Dhowabituhu, haalatuhu, asbabuhu, turqul wiqoyah minhu wasaili ilajihi fii du'i al-Qur'an wa Sunnah, Riyadh: al-Mamlakah al-Arabiyah as-Su'udiyah, 1415 H/1996 M.

Hasan, Mustofa, Pengantar Hukum Keluarga, Bandung: CV Pustaka Setia, 2011.

Kodir, Faqihuddin Abdul, dkk, Ed. Referensi Bagi Hakim Peradilan Agama Tentang Kekerasan Dalam Rumah Tangga, Jakarta: Komnas Perempuan, 2008.

Nata, Abuddin, Ilmu Pendidikan Islam Jakarta: Kencana Prenada Media Group, 2010.

Undang-Undang Nomor 23 Tahun 2004 Tentang Penghapusan Kekerasan Dalam Rumah Tangga.

Yunus, Mahmud, Kamus Arab-Indonesia, Jakarta: YP3A, 1987. 